\title{
Dergiabant
}

Cilt/Volume: 9, Sayı/Issue: 2

(Kasım/November 2021)

\section{Kırgız Örf-Âdetindeki Kalın Uygulamasının İslam Hukuku Açısından Analizi (18-19. yy)}

\section{Analytical Research on the Kalın Institution of Kyrgyz People from the Perspective of Islamic Law (18-19 cc.)}

\author{
Aiitmamat Kariev \\ Dr. Öğr. Üyesi, Karabük Üniversitesi, İslami İlimler Fakültesi, \\ Arap Dili ve Belagatı Anabilim Dalı \\ Asst. Prof. Dr., Karabuk University, Faculty of Islamic Sciences, \\ Department of Arabic Language and Rhetoric \\ Karabuk/Turkey \\ k.aytmamat@gmail.com \\ orcid.org/0000-0001-8976-3685 \\ $\underline{\text { Makale Bilgisi } \quad \text { Article Information }}$
}

Makale Türü: Araştırma Makalesi

Geliş Tarihi: 26 Ağustos 2021

Article Type: Research Article

Kabul Tarihi: 23 Kasım 2021

Date Received: 26 August 2021

Yayın Tarihi: 30 Kasım 2021

Date Accepted: 23 November 2021

Yayın Sezonu: Güz

Date Published: 30 November 2021

https://doi.org/10.33931/dergiabant.987307

İntihal/Plagiarism

Bu makale özel bir yazılımla taranmış ve intihal tespit edilmemiştir.

This article was scanned with a special software and no plagiarism was detected.

\section{Atıf/Cite as}

Kariev, Aiitmamat. "Kırgız Örf-Âdetindeki Kalın Uygulamasının İslam Hukuku Açısından Analizi (18-19. yy)". Dergiabant 9/2 (Kasım 2021), 748-765. https://doi.org/10.33931/dergiabant.987307

Copyright $\odot$ Published by Bolu Abant Izzet Baysal University Faculty of Theology, Bolu, 14030 Turkey. All rights reserved. https://dergipark.org.tr/tr/pub/dergiabant 


\title{
Kırgız Örf-Âdetindeki Kalın Uygulamasının İslam Hukuku Açısından Analizi (18-19. yy)
}

\begin{abstract}
$\ddot{O} \mathbf{z}$
Kırgız halkı arasında yaygın bir şekilde rastlanılan kalın adeti, felsefî olarak yeni kurulan aileye maddî destek düşüncesine dayanmaktadır. Diğer Türk boylarından örfî hukuku ön planda tutması ile farklılık arz eden Kırgız halkının kalın anlayışını konu edindiğimiz bu araştırmada, kısaca kalın tarihçesine değindikten sonra kalının türleri, ödeme süreleri, kalın olarak ödenen eşya türleri ve miktarları, kalının sosyal ve hukukî boyutu gibi konular üzerinde durulmuştur. Yarı göçebe hayat tarzını benimseyen ve kabileler şeklinde yaşayan Kırgız halkının, daha 18.-19. asırlarda bazı farklılıklar ile beraber mehrin temel felsefesi olan kadın haklarını koruma prensibini, aslında kalın aracılı̆̆ı ile gözettiği görülmüştür. Kalın, Kırgız halkının o dönemdeki kadına verdiği değeri ortaya koymakla birlikte, günümüzdeki kadının sosyal sigortası ile aynı özelliklere sahip olduğu, bu çalışmamızın sonucunda tespit edilmiştir. Kırgızların millî ve dinî kimliği düşüncesini bir arada tutan kalın adetinin, özellikle Çarlık Rusya ve SSCB döneminde ilga edildiği, böylece kalın müessesesinin tamamen ortadan kaldırıldığı tespit edilmiştir.
\end{abstract}

Anahtar Kelimeler: İslam Hukuku, Mehir, Kırgız, Örf-Âdet, Kalın.

\section{Analytical Research on The Kalın Institution of Kyrgyz People from \\ The Perspective of Islamic Law (18-19 cc.)}

\begin{abstract}
The kalın (bride price) tradition was pervasive in the Kyrgyz people and the explanation of this tradition it is financial support for newly married family. Kyrgyz people were adhered to customary law between Turkish tribes as a descry. In this article we will research on the different subjects that related with the bride price like; short history of kalın and its types, payment periods of bride price and types of the properties that payed as a bride price, it's background of social and law in the philosophy. Summarize, we can talk on the kalın as a women's rights and it was so early in 18-19 centuries in the society of Kyrgyz people. Shortly, we can say kalın was in the Kyrgyz society of women's value and social insurance in those days. Finally, kalın that used as a national and a religious identity it was annihilation by Tsarist Russia and USSR.
\end{abstract}

Keywords: Islamic Law, Mahr, Kyrgyz, Customs, Kalın (Bride Price).

\section{Giriş}

İslam öncesi Arap toplumundaki kadının herhangi bir şekilde mal sahibi olamadığı, hatta kendisinin bir eşya olarak kabul edildiği, kabile reisi gibi sadece bazı asil kadınların "mehir", "sadak", "sidak", "saduka" vb. malî değeri olan eşyalara sahip olduğu tarihî olarak herkes tarafından bilinmektedir. ${ }^{1}$ Feminizmin hedef aldığı İslam'ın, esasında kadın haklarını en iyi şekilde koruyan bir din olduğu, hiçbir şekilde tartışılamaz. Bu bağlamda, İslam öncesi kızın ailesine yapılan ödenek, İslam dininden sonra sadece kızın kendi hakkı olarak kanunlaştırılmıştır. ${ }^{2}$ Bununla beraber, miras eşyası olarak kullanılan kadına İslam dini mirastan pay alma hakkı tanımış, ${ }^{3}$ o günün toplumundaki sınırsız evlilikleri 4 sayısı ile

1 İbn Âbidîn, Muhammed Emîn, Hâşiyetu Reddü'l-muhtârr 'ale'd-Dürri'l-muhtâr (Beyrut: Dâru İhyâi'tTurâsi'l-Arabî, ts.), 2/329.

en-Nisâ 4/4, 20-25; el-Ahzâp 33/50; el-Bakara 2/229, 237.

en-Nisâ 4/7, 11, 12. 
sınırlandırmış, ${ }^{4}$ kocasından ayrılarak iddet beklemesi halinde başkalarına yük olmama veya maddî ihtiyaçtan dolayı hırsızlık veya zina yoluna girmeme teminatı olarak değerlendirilebilecek mehir alma hakkı vermiștir. ${ }^{5}$

Kırgız halkının M.Ö. 203 senesindeki eski Çin kaynaklarında zikredilmesi Türk tarihi bakımından dikkat çekici bir konudur. ${ }^{6}$ Kırgızlar İslamiyeti kabulünden önce Budizm, Maniheizm, Hristiyanlık, Gök Tengricilik dinlerine mensup olmuşlardır. ${ }^{7}$ Sonrasında komşu Karahanlılar Devleti ile Ulu Kırgız Kağanlığı arasındaki siyasî politika, ${ }^{8}$ diğer Müslüman devletler ile yapılan ticarî ilişkiler, kısaca dinî ve kültürel hayat gibi etkenler Kırgızların Müslümanlığı kabul etmelerinde etkili olmuştur. ${ }^{9}$ Kendi eserinde Kırgızlara ait bölüme yer veren ilk müslüman coğrafyacı İbn Hurdazbih (öl.272/886) olmuştur. İstahrî (öl.346/957) ise Kırgızların Taşkent (Şâş̧) ve İlak şehirlerinin yakınındaki Tanrı Dağlarının eteklerinde yaşadıklarını dile getirmiştir. Kırgızların ibadet ederken manzum dualar okuduklarını dile getiren tarihçi ise Ebu Dulef (öl. 390/1000) olmuştur. Bir diğer dikkat çekici açılama ise Gerdizî’nin (öl.453/1061) Kırgız halkının ölülerini yakma adeti ile ilgili olmuştur. Ancak, Mervezî (öl.614/1217) Kırgızların Kaşgar ve çevresindeki Müslümanlar ile olan etkileşiminden sonra, Kırgız halkının da ölülerini defnetmeye başladıklarını ifade etmiștir. ${ }^{10}$

Bu çalışmamızda, kısaca diğer Türk boylarına nazaran İslam dini ile daha geç tanışmış olan Kırgız halkının, Müslümanlığı kabul ettikten önceki ve sonraki kadın algısı, özellikle göçebe ve yarı göçebe hayat tarzının neticesinde elde ettikleri, hayat teminatı olarak kabul edilen kalın düşüncesinin ne tür değişikliklere uğradığı, İslam dininin bir emri olan mehri nasıl kabul ettikleri, bugüne değin hem kalın hem mehrin ikisinin de uygulama konusu olmasının İslam Hukukundaki yeri, bunun örfî hukukta nasıl tanzim edilmesi gerektiği vb. konular ele alınarak, kalın ve mehir üzerinden şerî ve örfî hukuk birleşmesini ortaya koymaya çalışacağız.

\section{Kalının Tarihçesi ve Tanımı Konusundaki Farklı Fikirler}

Temelde yeni kurulan aileye maddî destek felsefesine dayandırılan kalın, aile içi otorite sahibinin erkek ya da kadın olmasına göre değişik isimlerle adlandırılır, her iki tarafın aileleri ve gerektiği takdirde mensup oldukları kabileler tarafından ödemesi yapılabilirdi. Anaerkil toplumlar olarak bilinen Hindistan ve Trobriand Adalarında, bu maddî destek kızın ailesi tarafından damadın ailesine ödenmekte ve "drahoma" şeklinde isimlendirilmektedir.11 Diğer ataerkil toplumlarda; Romalılarda "dowry", Yahudilerde

el-Ahzâp 33/50; en-Nisâ 4/3.

el-Bakara 2/229, 237; en-Nisâ 4/4, 20-25; el-Ahzâp 33/50.

Ahmet Taşağll, Çin Kaynaklarına Göre Eski Türk Boyları (Ankara: Türk Tarih Kurumu, 2013), 75.

Ali Jusubaliev, Kırgızların Íslamiyeti Kabulü (Ankara Üniversitesi, Sosyal Bilimler Enstitüsü, Doktora Tezi, 2007), 31-36.

8 İbnü'l-Esir İzzuddin Ebi'l-Hasen Muhammed b. Muhammed b. Abdülkerim, el-Kâmil fi't-Tarih, çev. A. Ağırakça-Abdulkerim Özaydın (İstanbul: Bahar Yayınları, 1985-1987), 383, 288-289.

9 Detaylı bilgi için bk. Tabıldı Akerov, Karkırahan-Velikiy Kırgızskiy Kaganat (Bişkek: Tipografiya Univeristet KNU im. J. Balasagına), 2013; Viktor Butanaev - Modorov Nikolay, Kırgızskiy Kaganat: Pervie Ego Praviteli i ih Deyatelnosti (Altay: Word of The Great Altai, 2015), 1/4-8.

10 Jusubaliev, Kırgızların Íslamiyeti Kabulü, 3-5.

11 Viktor Barnouw, An Introdiction to Anthropology-Ethnology U.S.A (y.y., 1975), 164-165. 
"tamirtu-mohar", Afrikalılarda "labola", Türk kökenli halklarda "kalın" gibi isimlerle adlandırılmaktadır. Kalın kelimesi bütün Türk halkında ortak kelime olarak kullanılan eski bir kelimedir.12 Sadece Uygur Türklerinde kalın kelimesinin yerine "toyluğ" kelimesi kullanılmaktadır.13 Kalının tanımı konusunda Koca, "İslamiyet'ten önce Türk halkında oğlanın ailesi tarafından kızın ailesine verilen hediyelerin ismi kalındır" şeklinde betimleme yaparken,14 Ögel ise "Kalın, çeyize, annesinin süt hakkına veya ailesinin kızı yetiştirmesine karşılık olarak, erkeğin nişanlısını ilk ziyaretinde verilen kıymetli eşya” olarak tanımlamıştır. ${ }^{15}$ Kalının kızı satın alma bedeli olmadığına dikkat çeken Erkul, kısaca kalını erkeğin onur nişânesi olarak dile getirmiştir. ${ }^{16}$

Omurbekova'nın verdiği bilgilere göre Kırgızlardaki "kalın" kelimesi daha çok fazladan ödenen mal ödeneği ile yakından ilgilidir. ${ }^{17}$ Kırgız halkının gündelik örfî hukukunda hiçbir kimse kalın ödemeden gelin alma hakkına sahip olmamıştır. ${ }^{18}$ Ayrıca, bu Kırgız halkının yazılı hukuk kodifikasyon denemesi olarak kabul edebileceğimiz, 15 Mayıs 1893 yllında Tokmok şehrinde gerçekleşen Biy Mahkemelerinin ${ }^{19}$ resmî kararlarından biridir. ${ }^{20} \mathrm{Bu}$ da kalının örfî hukukta resmî boyut kazandığını göstermektedir. Bununla beraber, kalın ödeme adetinin Kırgız halkının aile yapısını konu edinen birçok çalışmada, tarihî olarak hangi asırlara kadar uzadığı net olarak dile getirilmemiştir. Ancak, en eski Kırgız kaynaklarından olan Manas Destanı'nda; “Aydap kelgen kalını” (Getirmiş olduğu kalını) şeklinde, Manas'ın müstakbel eşi Kanıkey'e vermiş olduğu kalından bahsedilmektedir. ${ }^{21}$ Kalının ödendiği eşyalara antropolojik açıdan yaklaşan Jacobs, genelde Orta Asya ve Afrika ülkelerinde kalının hayvanlar ile ödendiğini belirtmiştir.22 Burada mezkur halkların kalın adeti hakkında bilgiler vererek onların temelde hayvancılık ile geçimlerini sağladıklarına da işaret etmektedir. Aynı şekilde, Çin kaynaklarında da

12 A. İnan, Makaleler ve İncelemeler (Ankara: Türk Tarih Kurumu, 1998), 1/348.

13 Bk. Mairihaba Wufuer, "On Uigur Wedding Traditions and Change", Sosyal ve Kültürel Araştırmalar Dergisi 5/ 9 (2019), 169-191.

14 Salim Koca, Türk Kültürünün Temelleri - II (Ankara: Kültür Yayınları, 2010), 123.

15 Bahaettin Ögel, Dünden Bugüne Türk Kültürünün Gelişme Çağları (İstanbul: Türk Dünyası Araştırmaları Vakfi, 1988), 258.

16 Detaylı bilgi için bk. Ali Erkul, "Eski Türklerde Evlenme Gelenekleri”, Türkler Ansiklopedisi (Ankara: Yeni Türkiye Yayınları, 2002), 3. Kalın kelimesi, Kırgızcada "çok", "fazla”, "kalabalık”, "yoğun” gibi anlamlar ifade etmektedir. Detaylı bilgi için bk. Gulmira Omürbekova, "İstoriçeskoe Razvitie İnstituta Braçnogo Dogovora v Kırgızskoy Respublike", Vestnik Ekonomiçeskoy Bezapasnosti 1 (2018), 216. B. R. Saypidinov, "Braçno-Semeynı Otnoşeniya po Obıçnomu Provu Kırgızov v XIX v.", Vestnik KRSU1/15 (2015), 50.

Biy mahkemeleri, 18.-19. asırlarda Kırgız toplumundaki örfî hukuk esasında çalışan bir yargı müessesesi olmuştur. Bu bağlamda sadece nişanla ilgili değil, aslında toplumdaki bütün husumet ve dava konularıyla ilgili kararların son mercii olmuştur. Hatta Kırgız toplumundaki kurultay meclisinden sonraki en üst müessese olduğu söylenebilir. Biy mahkemelerinin yapısı, işleyiși, baktığı davalar, aldığı kararlar konusunda daha detaylı bilgi için bk. Aiitmamat Kariev, "Kırgız Biy Mahkemeleri Hakkında Kısa Bir Analiz", Manas Sosyal Araştırmaları Dergisi 6/4 (2017), 89-101.

20 Sost. B. İ. Börübaşov, Hrestometiya po İstorii Gosudarstva i Prava Kırgızstana: Ereje Tokmakskogo Çrezvıçaynogo Sezda Biev 1893 Goda (Bişkek: y.y., 2008) 1/441.

21 S.M.Abramzon, Kirgizi i ih Etnogenetiçeskie i Ístoriko-Kulturnıe Svyazi (Frunze: Kırgızstan, 1990), 234.

22 Jacobs-Stern, General Anthropology (у.у., 1968), 161. 
Kırgızların kalın adetine işaret edildikten sonra, Kırgız halkındaki kalının at ve koyunlar ile ödendiği bilgisi de yer almaktadır. ${ }^{23}$

\section{Kırgız Halkının Örf-Adetlerinde Yaygın Olan Kalın Çeşitleri}

Kırgız halkı arasında bugüne kadar uygulana gelen kalın adeti, zatı itibarı ile "beşik kertmesi usulü ile evlenen çocuklar için ödenen kalın", "normal bir evlilikte damat ailesinin kızın ailesine ödediği kalın”, "ölmüş ağabeyinin veya küçük kardeşinin karısını (yenge veya gelin) kendi nikahına alırken ödenen kalın", "karısı ölen birinin henüz evlenmemiş baldızını nikahlarken ödediği kalın"șeklinde birçok türe ayrılmaktadır ve ileriki konularda ayrıyeten bunların üzerinde durulacaktır. Burada zikri geçen dul yenge veya dul gelin ile evlenme konusunu Hz. Peygamber'in (s.a.v.) Zeynep ile evliliğine ve İmam Züfer'in ağabeyinin çocuklarına daha iyi bakabilmek için dul kalan yengesi ile evlenmesine dayandırabiliriz. ${ }^{24}$

Türkçedeki beşik kertmesi nişanının karşılığı olarak, Kırgız halkında çocukların daha annelerinin karnındayken yapılan söz kesmeye "Bel Kuda", çocukların beşikteyken yapılan nişanına "Beşik Kuda" ismi verilmiş, temel olarak iki farklı kısma ayrılmıştır. Hatta, Abramzon beşik kuda adetinin Kırgızların en eski örf-adetlerinden birisi olduğunu dile getirmiștir. ${ }^{25}$ Yukarıdaki nişan türlerinin yanında, Fielstrup Kırgız halkının yine dikkat çekici "Ok Tişteşken Kuda" şeklinde bir nişan ve kalın türü olduğuna işaret etmiştir. Bu tür nişanda müstakbel dünürlerin birbirine, ısırarak üzerinde iz bıraktıkları tüfek oklarını karşılıklı olarak değiş-tokuş yapması, ayrıca "Verilen sözü sen bozarsan bendeki bu ok, ben bozarsam sendeki o ok canımızı alsın" şeklinde kasem içmesi, esasen verilen söze sadık kalma amacı güttügünü dile getirmiştir. ${ }^{26}$

\section{Kalınların Ödenme Süreleri}

Beşik kuda adeti, Kırgız halkı içinde daha çok Alay bölgesindeki yakın arkadaşlar arasında, ${ }^{27}$ hayatın her türlü zor şartlarında birbirine destek çıkma amacıyla, daha eşlerinin hamile olduklarını birbirine müjdeledikleri zaman gerçekleşiyor ve sonrasında çocukların doğması ile kalın konusu konuşulabiliyordu. Bel kuda ve beșik kuda usulü ile yapılan her iki nişanda da kalın ödeme zorunluluğu vardı. Nişanlanma usulünün bu türüne dikkat çeken Argınbaev, Potanov, Kislyakov, Kambarova gibi bilim adamları, bu tür nişanlarda kalının evlenme gününe kadar taksitli olarak ödenebildiğini dile getirmişlerdir. ${ }^{28}$ Daha doğrusu,

23 N. Ya. Biçurin, Sobranie Svedeniy o Narodah: Obitavșih v Sredney Azii v Drevnie Vremena (Moskva: İzdatelstvo AN SSSR, 1950), 351-353.

24 Bk. İbrahim Acar, “İslam Hukuku Açısından Evlat Edinme ve Hz. Peygamber'in Zeynep’le Evliliği”, İslam Hukuku Araștırmaları Dergisi 7 (Nisan 2006), 99-110; Muhammed Zâhid el-Hasan el-Kevserî, Lamahâtü'n-Nazar fî Sîreti'l-İmam Zufer (Kahire: el-Mektebetü'l-Ezheriyye li't-Türâs, 1948).

25 S.M.Abramzon, Kirgizi i ih Etnogenetiçeskie i İstoriko-Kulturnıe Svyazi (Frunze: Kırgızstan, 1990), 238239.

26 F.A.Fielstrup, İz Obryadovoy Jizni Kirgizov Naçala XX Veka, nşr. B.H.Karmışova-S.S.Gubaeva (Moskva: NAUKA, 2002), 19.

27 N. İ. Grodekov, Kırgızı i Karakırgızı Sırdarınskiy Oblasti: Yuridiçeskiy Bıt (Taşkent: Tipolitografiya S.İ.Lathina, 1889), 55.

28 N. A. Argınbaev, Semya i Semeynıe Obryadı u Narodov Sredney Azii i Kazahstana (Moskva: y.y., 1978) 94105; L. P. Potanov, Nauçnaya Mısl (Taşkent: y.y., 1930); N. A. Kislyakov, Oçerki po İstorii Semi i Braka u Narodov Sredney Azii i Kazahstana (Leningrad: Nauka, 1969), 66-85; G. E. Kambarova, "Salttuu 
Kambarova'nın aktardığı bilgilere dayanarak, bel kuda nişanında çocukların sağ-salim doğması ile, beşik kuda nişanında ise 7-8-9 yaşlarındaki küçük kıza gümüş küpe takılmasından itibaren kalın ödenebiliyordu. ${ }^{29}$ Bununla birlikte, Kırgız halkında yaygın olan görüşe göre, kalının ödenmesi için evvela evlenebilecek kızın 15 yaşını doldurması şarttı. ${ }^{30}$ Bu tür nişan ve kalında kesilen söze sadık kalmamaya karşı güçlü bir hukuksal yaptırım söz konusu idi. Genellikle yakın arkadaşlar arasında gerçekleșen bu tür nişan ve kalına sadık kalınıyordu. Ancak, ergenlik çağına ulaşan damat beşikteyken sözü kesilen kız ile evlenmekten vazgeçtiği takdirde, daha öncesinde ailesi ve kendisi tarafından kalına mahsuben kızın ailesine ödemiş olduğu her şeyden mahrum bırakılması söz konusu oluyordu. ${ }^{31}$ Aynı şekilde, kızın ailesi verilen söze sadık kalmadan kızını başka birisi ile evlendirirse, bu durum da kızın ailesi damadın ailesine ödemesi zor olan "Bir Toguz"32 cezası ödüyordu. ${ }^{33}$ Eğer, beşik kuda usulü ile nişanlanan kızı başka birisi kaçırır ve evlenirse, bu durumda kaçıran damadın ailesi kızın akranlarına ödenen kalını, eskiden sözü kesilen eski nişanlısının ailesine ödemek zorundaydı. ${ }^{34}$

\section{Yaygın Olan Kalın Miktarları}

Kalının miktarı konusunda damadın ekonomik durumu, kızın bakire veya dul, güzel veya çirkin olması, ailelerin asaleti, kızın ailesinin hazırladığı çeyiz vb. faktörler etkili olmuştur. $^{35}$ Örneğin; Bay-manaplar (zengin tabaka) 100 at ve 30-40 koyun verebiliyordu. Orta halli bir damat ise 15-17 sığır verebiliyorken, toplumda fakir kabul edilen damat ise 910 inek verebiliyordu. Bununla birlikte damatların hepsi yeni bir çadır, halı, giysiler, ev eşyaları ödemek zorundaydı. Ayrıca, bunları taşıyacak bir at veya deve temin etme konusundan da sorumluydu. ${ }^{36} \mathrm{Bu}$ bağlamda, Kadırov'un verdiği bilgilere dayanarak Manas'ın babası Cakıp, kızın babası Atemir'e 500 at, 60 deve, 200 inek, 2000 koyun, 40000 tıyın ${ }^{37}$ ödediğini zikretmek yerinde bir örnek olacaktır. ${ }^{38}$

Kudalaşuudagı Irım-Cırımdar: Tüştük Kırgızstan Misalında", Nauka: Novıe Tehnologii i Ínavatsii Kırgızstana 12 (2015), 206-207.

Kambarova, "Salttuu Kudalaşuudagı Irım-Cırımdar: Tüştük Kırgızstan Misalında", 207.

S.K.Koconaliev, Obıçnoe Pravo Kırgızov (Bişkek: Fond Soros Kırgızstan, 2000), 85.

Ali Ünal, "Kırgız Toplumunda Evlilik Türleri", Hacetepe Üniversitesi Türkiyat Araştırmaları Üniversitesi Dergisi 25 (Güz 2016), 242.

Kırgız örfî hukukundaki "Bir Toguz" cezası 3 deve, 3 at, 3 inekten olușan herhangi bir cezânın ödeneğidir. Kendi içinde "Deve Baştagan Toguz", "At Baştagan Toguz" ve "İnek Baştagan Toguz" şeklinde üç kategoriye ayrılmaktadır. Hatta "Üç Toguz" cezâsı "Bir Toguzun" üçe katlanmasını, "Ceti Toguz Cezâsı" da "Bir Toguz Cezâsı"nın yediye katlanmasını ifade ettiğini belirtmekte fayda var.

U.R.Asanov - C.Ç. Tegizbekova, "Teoriya İ İstoriya Gosudarstva İ Prava”, Vestnik Sank-Petersburgskogo Universiteta MVD Rossii 4/52 (2011), 11; A. A. Abenova, "Nomadnoe Obșestvo i osobennosti Svadebnıh Obıçaev Kazahov (Po Materialam Rabot Dorevolyutsionnıh Rossiyskih Avtorov): İstoriçeskie Nauki i Arheologiya", Vestnik Altayskiy Gosudarstvenniy Universitet 63 (2017), 124.

Konuyla ilgili detaylı bilgi için bk. Aiitmamat Kariev, "Kırgız Halkının Nişanlılık ile İlgili Örf-Âdetlerinin İslam Hukuku Açısından Analizi (18-19.yy.)", Insan ve Toplum Bilimleri Araștırmaları Dergisi 9/5 (2020), 4167-4183; Grodekov, Kırgızı i Karakırgızı Sirdarınskiy Oblasti: Yuridiçeskiy Bıt, 58.

G. Zagryajskiy, "Kara Kirgizi”, Gazeta Turkestanskoe Vedomosti 41 (1871), 41.

Grodekov, Kırgızı i Karakırgızı Sirdarınskiy Oblasti: Yuridiçeskiy Bıt, 61,77,79-84; A.H.Dobrosmıslov, Taşkent v Proşlom i Nastoyaşşem: İstoriçeskiy Oçerk (Taşkent: y.y., 1912), 42-45.

Tıyın, Kırgız halkının 15 Mayıs 1993 yılına kadar, hatta günümüzde de kuruş anlamında kullandıkları para birimidir.

K. Kadırov, Kırgızstan: Traditsii i Obiçai Kirgizov (Bişkek: Raritet, 2005), 19. 
Kalın konusunu yerinde araştıran sosyolog Fielstrup, günümüz Isık-Göl'ünün Tüp şehrinde yukarıdaki miktarların zenginler için 100 büyük baş (at, inek, deve) ve 1000 koyun, orta durumdaki insanlar için 50 büyük baş ve 100 koyun, sıradan bir damadın da 25 büyük baş 50 koyun ödediğini dile getirmiştir. ${ }^{39}$ Kalının miktarı konusunda Makovetskaya Kırgız halkında 47-37-27 gibi sayıların kutsallığına işaret ederek, toplumdaki maddî durumu iyi olan ve orta olan veya zayıf olan insanların ortalama kalın miktarını yukarıdaki rakamlarla ifade etmiştir. ${ }^{40}$ Kalının miktarı konusundaki yukarıdaki farklı ölçülerden hareketle Polyakov, aslında kalının toplumdaki zenginler ile fakirler tabakasının birbirine karışmasını önleme amacıyla icat edildiğini dile getirmiştir. ${ }^{41}$

Dul kalan yenge ya da baldız ile yapılan evliliğin tarihi çok eskiye dayanır. Bu evlilik türü eski olduğu kadar çoğu Türk boylarında da yaygındır. Köse'nin verdiği bilgilere göre, bu tür evlilik Moğollara, hatta Hunlara kadar uzanan bir mâziye sahiptir. ${ }^{42}$ Kırgız halkı arasında da baldız ve yenge ile evlilik konusu yaygın bir âdetti. Öyle ki, karısı vefat eden erkeğin iddetini tamamladıktan sonra, ölmüş karısının kız kardeşini, yani baldızını kendi nikahına almasında herhangi bir anormallik görülmüyordu. ${ }^{43}$ Tabi ki, bu evlilikte "Baldız Kalını" ismiyle, yeni bir başlık parası ödeniyordu. Ancak, baldızı eniştesiyle evlenmek istemezse, bu durumda kızın anne-babası, eski damadına "Bir Toguz" cezası ödemek mecburiyetindeydi. ${ }^{4}$

Aynı şekilde, eğer koca ölürse, o halde kardeşlerinden biri, kendi yengesini nikâhına alabiliyordu. Bu tür evliliğe "Amangerlik" ismi verilirdi. Bu uygulama, Aynakulova'nın fikrine göre, sadece Kırgız halkı arasında değil, aynı zamanda bütün Orta Asya halkı arasında yaygınd. ${ }^{45}$ Hatta, Abramzon'un verdiği bilgilere göre, bu âdete müteallik meydana gelen özel hukukî uygulamalar da vardı. Onlardan biri de, dul kalan yengenin kayınları arasında tercih yapma hakkına sahip olmasıydı. ${ }^{46}$ Ayrıca, bu nikahtan sonra, yengesiyle evlenen erkek, aynı zamanda ağabeyinin çocuklarının nafakasından da sorumlu tutuluyordu. Vefat eden ağabeyinin karısı yaşlı olup, kimseyle evlenmek istemezse, bu durumda kimse onu evliliğe zorlayamazdı. Yine, küçük kardeşi ölürse, ölenin ağabeyi gelinini nikahına alır, onun ve çocuklarının nafakasından sorumlu tutulurdu. Eğer ölen adamın birkaç karısı ve kardeşleri varsa, bu durumda geride bıraktığı karılarının yaşları ve kardeşlerinin yaşları esas alınarak, adeta miras malıymış gibi taksim ediliyordu. Tabi ki, böylece anneleriyle beraber çocukları da ölenin kardeşlerinin himayelerine geçiyorlardı. ${ }^{47}$ Şayet, ölen damadın

39 Fielstrup, İ Obryadovoy Jizni Kirgizov Naçala XX Veka, 34.

40 P.E.Makovetskaya, Materialı: Dlya İzuçeniya Yuridiçeskih Obıçaev Kirgizov (Omsk: Tipog. Okruj. Ştaba, 1886), 5.

41 S. Polyakov, Everyday Islam: Religion and Tradition in Rural Central Asia (New York: y.y., 1992), 54-57.

42 Nerin Köse, "Eski Bir Evlenme Adeti ve Buna Bağlı Olarak Teşekkül Etmiş Halk hikayeleri”, Buca Eğitim Fakültesi Yayın Organı 2/3 (Ocak 1993), 82.

43 A. Cumagulov, Semya i Brak u Kırgızov Çuyskoy Dalinı (Frunze: y.y. 1960), 89.

44 N. M. Malıșev, Obıçnoe Semeynoe Pravo Kirgizov (Yaroslav: Tipografiya Guberskago Pravleniya, 1902), 33.

45 Gülnisa Aynakulova, "Kırgızlarda Evlilik ve Evlenme Törenleri”, Millî Folklor 72 (2006) 101.

46 S.M. Abramzon, Kırgız cana Kırgızıstan Tarıhı Boyunca Tandalma Emgekter (Bişkek: Kırgızstan Sooros Fondu, 1973), 61.

47 Malıșev, Obıçnoe Semeynoe Pravo Kirgizov, 34; A. İ. Dobromıslov, Sud u Kirgiz: Turgayskoy Oblasti v 1819 Vekah (Kazân: Tipo-Litografiya İmperatorskago Universiteta, 1904), 56-58; Grodekov, Kırgızı $i$ Karakırgızı Sırdarinskoy Oblasti-Yuridiçeskiy Bıt, 51. Yaşlı kadını evliliğe zorlamanın cezâsı deve baş olan 
erkek kardeşleri yok ise ve akrabalarının biri geline talip çıkar da kız reddederse, bu durumda almış olduğu başlık parasını ölmüş damadın ailesine geri vermek zorundaydı. ${ }^{48}$

Bu tür nikahlarda, esasen ölen insanın malını kaçırmama, arkada kalan çocuklarına daha şefkatli şekilde bakma, onları merhametten mahrum bırakmama vb. amaçlar güdülmüştür. İster yengenin ölen kocanın erkek kardeşlerinin biriyle, ister ölen kızın kız kardeşlerinin biriyle evlenen kocanın durumunda da her zaman aynı maksatlar gözetilmiştir. Bu mesele, tahrim ayetinde zikredilen hanımlar grubunda yer almadığından uygulanmasında bir beis yoktur. ${ }^{49}$ Yalnız bu tür meselelerde iddet konularına dikkat edilmelidir. Bu konuda, İmam Züfer'in ağabeyinin ölmesinden sonra yetim çocuklarına iyi bakmak amacında yengesiyle evlenerek Ebu Hanife'nin ders halkasından ayrılmasını örnek olarak zikredebiliriz.50 Ölen kocanın birkaç karısı ve birkaç erkek kardeşi olması durumunda, geride kalan kadınlarının yaşlarına göre kardeşleriyle evlendirilmesi, bu konuda sakınca olmasa da aslında kadının adeta bir miras eşyası olarak değerlendirildiğini göstermektedir.

\section{Kalının Hukuksal Zemini ve Sosyal Boyutu}

İnsanların karı-koca olarak birlikte ömür sürmeleri, onların en temel fitrî özelliğidir. Her toplum ailelerden oluşmaktadır. Bu nedenle toplum düzenini koruyan bazı kanunların olması da kaçınılmazdır. Böylece hukuk ve örf-adet kuralları çerçevesinde insanlığın mutluluğu ayakta kalabilmektedir. Kalın konusu ile ilgili örf-adetler de bu yönü ile önemlidir. Aksoy, kalının genel olarak Türk halkında eskiden kızın kendisine değil onun ailesine, hatta mensup olduğu kabileye verildiğini dile getirmiştir. ${ }^{51} \mathrm{Bu}$ konuyu daha spesifik alana taşıyan, daha doğrusu özel olarak Kırgız halkını araştırma konusu edinen Abramzon, kalının kızın mensup olduğu kabileye, veya onun akrabalarına, yada ailesine verilebileceğini dile getirmiștir. ${ }^{22} \mathrm{Bu}$ görüşü destekler mahiyette bir diğer çapraz görüş ise Anişkov tarafından, kalını ödeme konusunda sadece damadın ailesi değil, gerektiği takdirde "koşumça" adı altında akraba ve mensup olduğu kabile tarafından toplanarak ödenebileceği dile getirilmiştir. ${ }^{53} \mathrm{Bu}$ nedenle ilk bașta kalın, bir sosyal yardımlaşma olarak görülüyordu. ${ }^{54}$

dokuz olmuştur bk. Dobromıslov, A. İ., Sud u Kirgiz: Turgayskoy Oblasti v 18-19 Vekah (Kazân: TipoLitografiya İmperatorskago Universiteta, 1904), 48. Grodekov, Kırgızı i Karakırgızı Sırdarınskiy Oblasti: Yuridiçeskiy Bıt, 57; Dobrosmıslov, Taşkent v Proşlom i Nastoyaşşem: İstoriçeskiy Oçerk, 49-51.

49 Konuyla ilgili ayetin ahkamının çeşitli şekillerdeki yorumlar için bk. el-Cessâs, Ahmed b. Ali er-Râzî Ebu Bekr, Ahkâmü'l-Kurân (Beyrut: Dârü İhyâi't-Türasi'l-Arabî, 1984), 3/64; Ebü'l-Berakât Abdullah b. Ahmed b. Mahmûd en-Nesefî, Tefsirü'n-Nesefî (Beyrut: Dârü'n-Nefâis, 2005), 1/211. Detaylı bilgi için bk. Muhammed Zâhid el-Hasan el-Kevserî, Lamahâtü'n-Nazar fî Sîreti'l-İmam Zufer (Kahire: el-Mektebetü'l-Ezheriyye li't-Türâs, 1948).

51 Mustafa Aksoy, "Sosyal Hayatımızdaki Başlık-Kalın ve Mehir Kavramlarının Sosyolojik Tahlili", Insan Bilimleri Dergisi 8/1 (2011), 1-4.

52 Abramzon, Kırgız cana Kırgızıstan Tarıhı Boyunca Tandalma Emgekter, 233.

53 İ. Anişkov, K Voprosu o Kalıme: Oçerki Narodnoy Jizni Severnogo Turkestana (Taşkent: y.y., 1985), 3-4; İ.D.Starınkeviç, Formu Zaklyuçeniya Braka u Turetskih Plemen Sibiri i u Koçevnikov Sredney Azii (S.Petersburg: MAE, 1930), 9/233.

54 Cumagulov, Semya i Brak u Kırgızov Çuyskoy Dalinı, 96; Anişkov, K Voprosu o Kalıme: Oçerki Narodnoy Jizni Severnogo Turkestana, 20; Kislyakov, "Oçerki po İstorii Semi i Braka u Narodov Sredney Azii i Kazahstana”, 131; Abramzon, Kirgizi i ih Etnogenetiçeskie i İstoriko-Kulturnıe Svyazi, 480. 
Ancak, Zagrajskiy bu uygulamanın zamanla değişikliğe uğradığını, son zamanlarda kalının kızın kardeșlerine (ailesine) verildiğini dile getirmiştir. ${ }^{55}$

Kırgız aile hukukunu araştırma konusu edinen birçok şarkiyatçı bilim adamı, zikri geçen kalının neyin karşılığında verildiği konusunda, çok farklı görüşler ileri sürmüşlerdir. Malışev, Kırgızlardaki kalının gelinin bedeli olduğunu, bu yüzden gelinlerin adeta cariye olarak kullanıldığını dile getirmiştir. ${ }^{56}$ Buna yakın bir görüşü savunan Koconaliev "Karımı istediğim kadar dövebilirim. Şayet, o ölecek olursa, ailesine diyet öderim" şeklindeki algıdan hareketle, esasında kalının gelinin bedeli olduğunu imâ etmiştir. ${ }^{57}$ Konuyu yerine gidip araştıran karı-koca Nalivkin ve Nalivkina, Kırgız halkındaki kalının çeyizin karşılığında ödenen bir ücret olduğu söylemişlerdir. ${ }^{58}$ Nitekim, Türk halklarındaki evlilikte çeyiz çok önemli bir unsur olarak kabul edilmiştir. Tarihte sırf bu yüzden Selçuklu ve Karahanlı devletlerinin arasının bozulması da söz konusu olmuştur. ${ }^{59}$ Tegizbekova, kalının Kırgız halkında mülk edinme yöntemi olarak varlığını devam ettirdiğini ileri sürmüştür. ${ }^{60}$ Abaşin, kalının tamamen ödenmediği takdirde kızın ailesinin kızını damadın evine göndermeme hakkına sahip olduğunu dile getirerek, aslında kalının kızın bedeli olduğuna işaret etmiştir. ${ }^{61}$ Zagryajskiy, kalının sadece ekonomik bir olgu olmadığına, bu sebeple Kırgız kızının aynı inanca sahip olmayan birisi ile evlendirilmediğine dikkat çekmiştir. ${ }^{62} \mathrm{Bu}$ bağlamda Makovetskaya, Kırgızlardaki kalın uygulamasının mitolojik anlamda kutsal bir adet olduğunu söylemiştir. ${ }^{63}$ Eşmuradova, kalının bir alım gücü olduğuna, bu sebeple onu ödeyebilenler için çok evliliğin kapısını açtığına değinmiştir.64 Kırgız hukuk tarihçisi Börübaşov, levirat evlilikteki temel felsefenin geline ödenen kalının gelin bedeli olarak algılanmasına dayandığını dile getirmiştir. ${ }^{65}$ Polyakov, kalının temel felsefesini toplumdaki elit tabaka ile sıradan halkın asimile olmaması için icat edilen bir sınırlandırma olarak dile getirmiştir.66

Türkiye'de başlık ve mehir gibi konularda çok sayıda nitelikli çalışmalar mevcuttur.67 Osmanlı İmparatorluğu'ndaki kalın uygulaması hakkındaki görüşlerin

G. Zagryajskiy, "Yuridiçeskiy Obiçay Kirgizov", Materialı Dlya Statistiki Turkestanskogo Kraya, (y.y., 1876), 27-28.

56 Malışev, Obıçnoe Semeynoe Pravo Kirgizov, 10-11.

57 Koconaliev, Obıçnoe Pravo Kırgızov, 85-86.

58 V. Nalivkin, Oçerk Bıta Jenşinı Osedlogo-Tuzemnogo Naseleniya Ferganı (Kazan: y.y., 1886), 202, 207.

59 Bk. Bülent Kaçın, "Büyük Selçuklular'da Evlilik Merasimleri”, Selçuklu Medeniyet Araştırmaları Dergisi 2 (2017), 112-113.

$60 \quad$ Cıldız Tegizbekova, Obıçnoe Pravo Kırgızov: Brak i Semya (Bişkek: Alatoo, 2016) 136-137.

61 Sergey Abaşin, "Kalım i Mahr v Sredney Azii: Pravo ili Ritual", Çelovek i Prava, Zvenigorod: Institut Etnologii i Antropologii RAN (1999), 155-161.

62 Bk. G. Zagryajskiy, "Yuridiçeskiy Obiçay Kirgizov", Materialı Dlya Statistiki Turkestanskogo Kraya (y.y., 1786).

63 P.E.Makovetskaya, Materialı: Dlya İzuçeniya Yuridiçeskih Obıçaev Kirgizov (Omsk: Tipog Okruj.Ştaba, 1886), 5.

64 N.D.Eşmuradova, "Pravove Polojenie Jenşin v Kırgızskom Traditsionnom Obșestve”, Interactive Science 13 (2017), 184-185.

65 B. İ. Börübașov, İstoriya Gosudarstva i Prava Kırgızskoy Respubliki (Bișkek: y.y., 2015), 302.

66 Polyakov, Everyday Islam: Religion and Tradition in Rural Central Asia, 54-57.

67 Bk.İhsan Hınçer, "Türklerde Mehir ve Başlık", I. Uluslararası Türk Folklor Semineri Bildirileri (Ankara: T.C. Başbakanlık Kültür Müsteşarlığı Millî Folklor Araştırmaları Dairesi Yayınları, ts.), 9/391-398; Mustafa Aksoy, "Başlık ve Mehir Kavramları Üstüne Bir Deneme", Türk Dünyası Araştırmaları Dergisi 73 (Ağustos 1991), 87-90. Ayrıca Hz. Peygamber dönemi mehir uygulamaları konusunda bk. Ayșe Betül 
mukayese babından burada zikredilmesi önemlidir. Öncelikle Osmanlı İmparatorluğu'nda başlık ve kalın kelimelerinin birbirinin eşanlamlıları olarak kullanıldığını belirtmemizde fayda vardır.68 Kalın ile ilgili Çin kaynaklarını araştırma konusu edinen Kapusuzoğlu, Türk halkının ilk evlenme usullerinden bahsederken damadın iç güveysi olarak kızın ailesine gittiğini, ilk çocukları oluncaya dek onun ailesinde hizmet ettiğini, çocukları doğduğu zaman ancak kendi evlerine dönebildiklerini ifade etmiştir. ${ }^{99}$ Hatta, aynı müellifin kalın ödemeye gücü yetmeyenlerin kızı kaçırmasına yol açtığına işaret etmesi dikkat çekicidir. ${ }^{70}$ Benedict, kalının kocanın karısına erkek çocuk doğurarak kendisinin neslini devam ettirmesi için ödediği bir ücret olduğunu dile getirmiştir. ${ }^{71}$ Osmanlı İmparatorluğu'ndaki kadınların statüsünü inceleyen Maydaer, kalının Osmanlı Devleti'nde kadınların servet edinme yollarından biri olduğunu dile getirmiştir. ${ }^{72}$ Gönen, kalının kız kaçırmanın önüne geçme amacıyla icat edildiğine işaret etmiştir. ${ }^{73}$ Ögel, kalın tanımı konusunda "Kalın, babanın sağ iken oğullarının evlenebilmeleri için verdiği paydır" şeklinde kendi fikrini bildirirken, ${ }^{74}$ bir diğer konu altında "evlenen bir gelinin boşanma amacıyla baba evine döndüğü takdirde, kocasının ailesinden alınan kalını iade etmek zorunda olduğunu" bildirerek, kalının dolaylı olarak gelinin bedeli olduğunu dile getirmiştir. ${ }^{75}$ Türkdoğan, "Başlık, her devirde, her zaman sosyal değişme sürecine uygun olarak kılık değiştirmiştir" şeklindeki ifadesiyle, aslında kalının her toplumda daima varlığını koruduğunu ve koruyacağını dile getirmiştir. ${ }^{76}$

18.-19. asırlarda ve öncesinde yaşayan Kırgız halkında nişan hukukî bir yaptırımı olan akit olarak kabul edilmiștir. ${ }^{77}$ Böyle bir algının ardında, onların devlet düzeninden daha çok kabileler şeklinde, göçebe ve yarı göçebe olarak hayat sürmeleri, bu sebeple kalının kadının bir nevi sosyal sigortası olarak kabul edilmesi düşüncesi yatmaktadır. Bu bağlamda, kalının ayrılma sonrasında karı koca arasında taksim edilmesinden hareketle, kalının bir sosyal sigorta olduğu ve kadına iade edildiğinden, sanki bir nevi manevi tazminat olarak da değerlendirilebilir. ${ }^{78} \mathrm{Bu}$ nedenle, nişan yapılırken daha sonrasında husumet olmaması için, nişan meclisinde damat ve gelin adaylarının her ikisinin de bulunması zorunlu

Algül-Ömer Faruk Habergetiren “Hz. Peygamber Dönemi Mehir Miktarları ve Günümüzdeki Karşılıkları”, Pamukkale Üniversitesi İlahiyat Fakültesi Dergisi 6/12 (2019), 209 - 232.

68 Bk. Tülay Ercoşkun, Osmanlı İmparatorluğunda 19. Yüzyılda Evlilik ve Nikaha Dair Düzenlemeler (Ankara Üniversitesi, Sosyal Bilimler Enstitüsü, Doktora Tezi, 2010).

69 Gökçen Kapusuzoğlu, "Çin Kaynaklarına Göre Türk Kültür Çerçevesinde Evlenme ve Cenaze Gelenekleri”, Tarih Araștırmaları Dergisi 34/58 (2014), 515.

70 Kapusuzoğlu, "Çin Kaynaklarına Göre Türk Kültür Çerçevesinde Evlenme ve Cenaze Gelenekleri”, 516.

71 Peter Benedict, Hukuk Reformu Açısından Başlık Parası ve Mehr (Ankara: Türkiye Kalkınma Vakfı Yayınları, 1974), 4.

72 Bk. Saadet Maydaer, "Osmanlı Klasik Döneminde Kadınların Servet Edinme Yolları (Bursa Örneği)”, Uludağ Üniversitesi İlahiyat Fakültesi Dergisi 15/2 (2006), 30-46.

73 Bk. Sinan Gönen, "Türk Kültüründe Kız Kaçırarak Evliliğin Köy Seyirlik Oyunlarındaki İzleri”, Selçuk Üniversitesi Türkiyat Araștırmaları Dergisi 29 (2010), 45-55.

Bahaaettin Ögel, Türk Kültürünün Gelişme Çağları (İstanbul: Millî Eğitim Basımevi, 2001), 252.

Bahaaettin Ögel, Türk Kültürünün Gelişme Çağları (İstanbul: Millî Eğitim Basımevi, 1979), 179.

Orhan Türkdoğan, "Evlenmedeki Başlık Geleneğinin Sosyolojik Açıllaması", Uluslararası Folklor Kongresi Bildirileri IV (1976), 315.

77 Bk. Aiitmamat Kariev, "Kırgız Halkının Nişanlılık ile İlgili Örf-Âdetlerinin İslam Hukuku Açısından Analizi (18-19.yy.)", İnsan ve Toplum Bilimleri Araştırmaları Dergisi 9/5 (Ekim 2020), 4167-4183.

78 Bk. Hasan Tanrıverdi, “İslam Hukukunda Boşanma Tazminatı (Mut'a)”, Elektronik Sosyal Bilimler Dergisi 38/10 (Güz 2011), 443-463. 
tutulmuştur. ${ }^{79}$ Hatta, nişan yemeği hazırlanarak mahalle ahalisine ilan edilmesi de adet olmuştur. Nitekim bu uygulamayı günümüz Türkiye'sinin Van iline bağlı Ulupamir köyündeki Kırgız halkı arasında da görmek mümkündür. Kısaca, kızın babasının tertip ettiği yemekte mahalle aksakallarının kalın miktarını belirlemesi, ardından onların şahitliğinde kızın babasına kalının teslim edilmesi söz konusudur. Bugün Van'daki kalın miktarları bin dolar civarında olup, genelde düğün masrafları ve çeyiz için harcanmaktadır. ${ }^{80}$

\section{Kalın ve Mehrin Benzer Yönleri ve Ayrıștığı Konular}

İslam Hukukunda sadak, ${ }^{81}$ nihle, ${ }^{82}$ atiyye, ${ }^{83}$ farîda, ${ }^{84}$ ucûr, ${ }^{85}$ ukr, ${ }^{86}$ saduka, ${ }^{87}$ alâik ${ }^{88}$ gibi mehir konusu ile yakından ilgili olan terimler bulunmaktadır. Bu terimlerin temelinde kadını koruma felsefesi yer almaktadır. Bu nedenle Hanefiler, mehir konusunu nikah sonucunda, kocadan alacaklı konumunda olan kadının bizzat kendi hakkı olduğuna işaret etmişlerdir ${ }^{89}$ Hatta, Hanbelilerin mehri nikah akdinin sıhhat şartlarından kabul etmeleri de buna dayanmaktadır.90 Örnek olarak, Yahudilikte mehrin nikah akdinin yapıcı unsuru olarak kabul edildiğini, mehirsiz kıyılan nikahın da batıl olduğunu belirtmekte fayda vardır. ${ }^{91}$

Bununla beraber, İslam Hukukunda mehri erkeğin kadını boşama, ayrıyeten yukarıda zikrettiğimiz gibi çok evlilik hakkının bedeli olduğu da ifade edilmiştir. ${ }^{92}$ Hatta, Hanbeliler babanın mehrin tümünü veya bir kısmını kendisine verilmesini şart koşabileceğini ileri sürmüşlerdir. ${ }^{93}$ Yukarıdaki görüşün felsefesi, babanın erkek çocuğunun malında hakkının olmasına kıyas edilmiş, hatta günümüz Suudi Arabistan'ında fetva

79 Grodekov, Kırgızı i Karakırgızı Sırdarınskiy Oblasti: Yuridiçeskiy Bıt, 58-59.

80 Murat Özer, "Ulupamir Kırgızlarında Evlilikle İlgili Gelenekler", Uluslararası Türkçe Edebiyat Kültür Ĕ̆itim Dergisi 5/2 (2016), 875.

en-Nisâ $4 / 4$.

en-Nisâ $4 / 4,6$.

Ebû Bekr Şemsü'l-Eimme Muhammed b. Ebî Sehl Ahmed es-Serahsî, el-Mebsût (Kahire: Matbaatü'sSaade, 1324-1331), 3/62.

el-Bakara 2/236-237; en-Nisâ 4/24.

en-Nisâ 4/24-25; el-Mâide 5/5; el-Ahzâb 33/50; el-Mumtehine 60/10; Talâk 65/6.

Seyyid Șerif el-Curcânî, Ali b. Muhammed b. Ali, Kitâbü't-Tarifât, thk. İbrahim el-Ebyârî (Kâhire: Dârü Îrân li't-Turâs, 1982), 196. en-Nisâ 4/4, 24, 25.

Muhammed b. Ahmed el-Hatîb eş-Şirbinî, Mugni'l-muhtâc (Beyrut: Dârü'l-kütübi'l-i'lmiyye, 1993), $4 / 367$.

89 Abdurrahman b. Muhammed b. Suleyman el-Küleybûlî (Șehzâde), Mecmaü'l-enhur fí șerhi Multeka'lebhur (Beyrut: Dârü'l-kütübi'l-i'lmiyye, 1998), 2/508-509.

90 İbn Kudâme, Abdullah b. Ahmed el-Makdisî, el-Mugnî fî fikhi'l-Imam Ahmed b. Hanbel eş-Şeybânî (Beyrut: Dârü'l-fikir, 1984), 8/7.

91 Abdurrahman Sâbûnî, Şerhu Kavâini'l-ahvâli'ş-şahsiyye es-Sûrî (Dımaşk: y.y., 1989), 1/224.

92 H. Sağlam, "İslam Hukukunda Mehir Evlilik Sigortası mıdır?", Universal Journal of Theology 1/1 (2016), 6-7.

93 İbn Kudâme, el-Mugnî fî fikhi'l-İmam Ahmed b. Hanbel eş-Şeybânî, 10/118-121; Merdâvî, Alâuddin Ebü'lHasen Ali b. Suleyman b. Ahmed, el-İnsâf fi ma'rifeti'r-racih mina'l-hilâf alâ mazhabi'l-İmam Ahmed b. Hanbel, thk. Ebu Abdullah Muhammed Hasan İsmail (Beyrut: Darü'l-kutubi'l-ilmiyye, 1997), 8/248; Buhûtî, Mansur b. Yunus, Keșşâfü̈'l-Kinâ 'ani'l-İknâ (Riyad: Vizaretü'l-Adâleti's-Suudiyye, 2000), 11/465. 
kurumları, mehrin ayetçe kadının hakkı olduğuna işaret edilse dahi babanın alması durumunda günahkar olmadığına hükmetmişlerdir. ${ }^{94}$

Mehir, miktarına göre mehr-i musemmâ ve mehr-i misil, ödeme zamanına göre de mehr-i muaccel ve mehr-i müeccel şeklindeki kısımlara ayrılmaktadır. Mehrin alt sınırı konusunda, Şâfiî ve Hanbelilerde belli bir miktar ile sınırlandırma söz konusu değilken, mehrin felsefesini esas alan Hanefîler en az 10 dirhem, Malikiler ise 3 dirhem ile sınırlandırmışlardır. ${ }^{95}$

Mehir nikahın gerçekleşebilmesinin şartlarından değil onun sonucunda damadın geline ödemesi gereken borç olarak ortaya çıkmaktadır. Mehrin bir borç olduğuna dikkat çeken Hanefiler, mehri evliliğin bir sonucu saymış, damadın geline ödemesini de vacip hükmünde değerlendirmişlerdir. Mehir ile ilgili ayet ve hadislere baktığımız zaman mehrin bizzat kızın malı olduğuna işaret edilmiştir. Hanefilerin mehrin en az 10 dirhem olmasını şart koşmalarına dayanarak, mehir ile boşanan kadının iddet beklerken sosyal bakımdan başkalarına muhtaç olmaması amacı güdüldügünü ifade etmek mümkündür. Burada iddet bekleyen kadının mehirsiz kaldığı durumlarda hırsızlık veya zina gibi eylemlerle sosyal düzeni bozmaması amaç edinilmiştir.

Türk kültüründe kadınların yeri önemli olduğundan boşanan kadın sokağa bırakılmıyordu. Almış olduğu kalın karşılığında hazırladığı çeyizine sahiplik etmeye devam ediyordu. Bu da Kırgız halkında kadına verilen bir hak idi. Ayrıca, bu bağlamda asr-ı saadette on dirhem iki koyun satın alma gücüne sahip iken, 18-19. Yüzyıllardaki Kırgız toplumunda kalın olarak verilen mezkur hayvanların sayı bakımından oldukça fazla olması, özellikle dikkat çeken bir diğer husustur. Bu yönü ile kalın hem sosyal hem hukuksal yönü ile o dönemlerdeki kadını koruma kurumu olarak değerlendirilebilir.

Hatta, mehrin alınıp verilmesi sadece karı koca arasında gerçekleşirken, kalının aile ve kabilelerin tanıklığı ile gerçekleşmesi, dolayısıyla son dönemlerde su-i istimal edilen mehir konusundan daha güçlü bir kurum olduğu açıktır. Mehir ve kalının ister hukuksal ister sosyal yönüne baktığımız zaman her ikisinin benzer yönlerini günümüz ifadesi ile sosyal sigorta şeklinde değerlendirmek mümkündür.

Mehir sadece kıza verilirken ve onun hibe etmesi veya rızası olmadan geri alınamaması söz konusu iken, kalın kızın kendisine, ailesine veya velayet hakkı olan şahıslara verilmiş, gerektiği takdirde damadın onlardan geri isteyebilmesi söz konusu olmuştur. Özellikle bu durumu ayrılmalarda ve miras paylaşımında net bir şekilde görmek

94 Ahmed b. Abdurrazzak Düveys, Fetâva'l-lecneti'd-dâime li'l-buhusi'l-ilmiyye ve'l-iftâ (Riyad: Dârü'l-Âsime, 2003), 19/66, 68-69. Aslında son dönemlerde Suudi Arabistanı'nda bizim bahsetmekte olduğumuz kalın felsefesi ile bu uygulamanın ardında kadının her iki toplumda da sosyal güvencesi yer almaktadır. Suudi Arabistan'daki mehir ve kalın anlayışının benzer yönleri hakkında detaylı bilgi için bk. Mehmet Ali Yargı, “Suudi Arabistan'daki Mehir Uygulamalarına Dair Bir İnceleme”, Kilitbahir 15 (Eylül 2019), 229-294.

95 İbn Kudâme, el-Mugnî fî fikhi'l-İmam Ahmed b. Hanbel eş-Şeybânî, 6/680; İbnü'l-Hümam, Kemâlüddîn Muhammed b. Abdilvâhid b. Abdilhamîd es-Sivâsî, Şerhü Fethi'l-Kadir (Beyrut: y.y., 1970), 3/317; Şirbinî, Mugni'l-muhtac (Beyrut: Darü'l-fikr, ts.), 3/220; Muhammed b. Abdillah el-Haraşî, Şerhü Muhtasari Halil (Beyrut: Darü Sâdır, 1899), 3/262. 
mümkündür. Verilen mercii ve geri alınıp alınamaması bakımından mehir ve kalın yukarıdaki gibi birbirinden farklılık arz etmektedir.

Kalın ile mehrin bir diğer benzer yönleri de, her ikisinin de Müslüman topluluklarında erkek ailesinden kızın ailesine verilmesi söz konusudur. Bu yönü ile kız tarafının mehri ve kalını mülk edinme haklarına sahip olmaları söz konusu olmuştur. Ancak, burada kalının bazen kızın babasının mülkiyetine geçmesi, babasının önceki malları ile karıștırılan kalın mallarının babası vefat edince, aynı kızın kalınının diğer kardeşleri arasında taksim edilmesi, bu nedenle Kırgız örf - adetindeki miras uygulamalarında İslam Miras Hukuku gibi net prensiplerin olmadığı tespit edilmiştir. Hatta, ayrılık olduğu takdirde kalına karşılık hazırlanan çeyizin kadının malı olarak görülmesi, bazı durumlarda ortak bir şekilde paylaştırılması da söz konusu olmuştur. Yine, çeyize karşılık ödenen kalın malının damadın vefat etmesi durumunda, çeyiz ile karışık bir mal haline geldiği için kadına terekenin yarısının verildiğini dile getirmekte fayda vardır. ${ }^{96}$

\section{Kalın Uygulamasının SSCB Tarafından İlgası: Millî-Dinî Kimliğin Baltalanması}

Yayılmacılık politikası ile Orta Asya'yı işgale koyulan Çarlık Rusya, askerî açıdan olduğu gibi kültürel açıdan da yerli ahaliyi etkisi altında bırakmış, Bolşeviklerin iktidara gelmesi ile daha da sıkı kontrol altına alınmıștır. Böylece 15 Kasım 1917 tarihinde "Rusya Halklarının Hakları Hakkındaki Deklarasyonu" kabul edilirken, 27 Ocak 1918 "Arazilerin Kamulaştırılması" kanunu, 10 Temmuz 1918 “Kadın Erkek Eşitliği” kararı, 14 Haziran 1921 yılında "Kalın ve Çok Evliliğin Kaldırılması" gibi kadın haklarını konu edinen kararnameler kabul edilmiştir. ${ }^{97}$ Aslında, tüm bu kararnameler, SSCB devletlerindeki farklı milletlerin dinî ve millî kimliklerini tedricî olarak unutturmak, sonrasında tek tip SSCB insanını yaratmak, böylece büyük bir birlik devleti ikame etmek için önceden tasarlanan bir projenin ilk adımları olmuştur.

Bu bağlamda, 17 Ocak 1921'de resmî olarak yürürlüğe konulan “Kalın ve Çok Evliliğin Kaldırılması" kararnamesinde, Türkistan'da kalının bir kadın bedeli olarak telakki edildiğine, kadınların adeta cariye yerine konulduğu ve insan yerine konulmadan haklarının ihlal edildiğine işaret edilerek, örfî hukuktaki kalın uygulamasının iptal edildiğine, kalının hukukta yeri olmadığına, kalın talep eden tarafın karşı tarafa aynı kalının iki katını ödeme cezasına çarptırılacağına, kalın alış-verişinde bulunan her iki tarafa da bir sene hapis cezası verileceğine, suçun işlendiği günden sonra üç senesini doldurmuş suçların muaf tutulacağına karar verilmiştir.98 Hemen akabinde 1924 senesinde kurulan SSCB devletlerine bağlı olan diğer Orta Asya ülkeleri gibi Kırgız halkında da, bu kararlar yetmiş

96 Börübaşov, B. İ., "Regulirovanie İmuşestvennıh Otmoşeniy Kırgızov Po Adatu”, Vestnik KRSU 9/1 (2009), 39.

97 Koconaliev, Obıçnoe Pravo Kırgızov, 126-127.

98 Proekt Uprazdneniya Narodnıh Sudov v Turkestanskom Krae (Taşkent: Tipografiya Kantselyarii GeneralGubernatora, 1910), 1; Koconaliev, Obıçnoe Pravo Kırgızov, 127,135. 
yıl boyunca hukukî gücünü kaybetmemesi, hatta çok sıkı takip ile Kırgız halkının millî ve dinî kimliklerini unutturmaya çalıştırılması söz konusu olmuştur. ${ }^{99}$

\section{Sonuç}

Evlilik müessesinin temelini oluşturan kalın adeti insanlık tarihi kadar eskidir. Kalın tarihçesi konusu altında da değindiğimiz gibi, henüz İslam dini gelmeden dünyanın her köşesinde yaşayan insanlarda kalın düşüncesi, asırlarca varlığını korumuştur. Yeni kurulan aileye destek çıkma felsefesine dayandırılan Kırgız halkının kalın adeti, Kırgızların en eski adetlerinden biri olmuştur. Zamanla bu uygulama kendi içinde "beşik kertmesi kalını", "normal evlilik kalını", "dul yenge ve dul gelin kalını", "baldız kalını" şeklinde taksime uğramıştır. Kalını ödeme süreleri de kalın türlerine göre farklılık arz etmiştir. Kırgız halkı arasında yaygın olarak görülen kalın miktarlarında, damadın ekonomik durumu, kızın bakire veya dul, güzel veya çirkin olması, ailelerin asaleti, kız tarafının hazırladığı çeyiz vb. faktörler etkili olmuştur. Bulunduğu jeopolitik konumu gereği göçebe ve yarı göçebe bir hayat tarzını benimseyen Kırgız halkı, 840-1212 seneleri arasında kurdukları Büyük Kırgız Kağanlığı devletinden sonra asırlarca kabileler şeklinde yaşamış, kalın başta olmak üzere çoğu örf-adetini buna göre şekillendirmiştir. Genelde yeni kurulan aileyi maddî olarak destekleme düşüncesine dayanan kalın, aynı zamanda nişan da birer hukukî akit olarak algılanmasına sebep olmuş, böylece asırlardır kalının sosyal ve hukukî yönüne dikkat çekilmiştir. Ayrılmadan sonra kalın karşılığı hazırlanan çeyize sadece kadının sahip olmasından hareketle, Kırgız halkının 18.-19. yüzyıllardaki kalın anlayışını, kadının günümüzdeki sosyal sigortası olarak değerlendirebiliriz. Yukarıda mehir ve kalının benzer ve farklı yönlerini de mukayese ettikten sonra, bu araştırmamızın sonucunda kalın müessesesinin Kırgız halkı arasındaki sosyal ve hukukî yönünü de göz önünde bulundurarak, aslında kalının bazı farklılıklarla beraber mehrin kadını koruma felsefesi ile aynı amacı güttüğüne, hatta kalın müessesinin sistemsel olarak daha sağlam olduğu kanaatine ulaştık. 
762 | Kırgız Örf-Âdetindeki Kalın Uygulamasının İslam Hukuku Açısından Analizi (18-19. yy)

\section{Kaynakça}

Abaşin, Sergey. "Kalım i Mahr v Sredney Azii: Pravo ili Ritual". Çelovek i Prava, Zvenigorod: Institut Etnologii i Antropologii RAN (1999), 155-161.

Abenova, A. A. "Nomadnoe Obşestvo i osobennosti Svadebnıh Obıçaev Kazahov (Po Materialam Rabot Dorevolyutsionnıh Rossiyskih Avtorov): İstoriçeskie Nauki i Arheologiya". Vestnik Altayskiy Gosudarstvenniy Universitet (2017/63), 121-124.

Abramzon, S.M. Kırgız cana Kırgızıstan Tarıhı Boyunca Tandalma Emgekter. Bişkek: Kırgızstan Sooros Fondu, 1973.

Abramzon, S.M. Kirgizi i ih Etnogenetiçeskie i İstoriko-Kulturnıe Svyazi. Frunze: Kırgızstan, 1990.

Acar, İbrahim. “İslam Hukuku Açısından Evlat Edinme ve Hz. Peygamber'in Zeynep’le Evliliği”. İslam Hukuku Araştırmaları Dergisi 7 (Nisan 2006), 99- 110

Akerov, Tabıldı. Karkırahan-Velikiy Kırgızskiy Kaganat. Bişkek: Tipografiya Univeristet KNU im. J. Balasagina, 2013.

Aksoy, Mustafa. "Başlık ve Mehir Kavramları Üstüne Bir Deneme". Türk Dünyası Araștırmaları Dergisi 73 (Ağustos 1991), 87-90.

Aksoy, Mustafa. "Sosyal Hayatımızdaki Başlık-Kalın ve Mehir Kavramlarının Sosyolojik Tahlili". İnsan Bilimleri Dergisi 8/1 (2011), 1-4.

Algül, Ayșe Betül- Habergetiren, Ömer Faruk. "Hz. Peygamber Dönemi Mehir Miktarları ve Günümüzdeki Karşıllkları”. Pamukkale Üniversitesi İlahiyat Fakültesi Dergisi 6/12 (2019), $209-232$.

Anişkov, İ. K Voprosu o Kalıme: Oçerki Narodnoy Jizni Severnogo Turkestana. Taşkent: y.y., 1985.

Argınbaev, N. A. Semya i Semeynıe Obryadı u Narodov Sredney Azii i Kazahstana. Moskva: y.y., 1978.

Asanov, U.R.- Tegizbekova, C.Ç. "Teoriya İ İstoriya Gosudarstva İ Prava". Vestnik SankPetersburgskogo Universiteta MVD Rossii 4/52 (2011), 10-15.

Aynakulova, Gülnisa. “Kırgızlarda Evlilik ve Evlenme Törenleri”. Millî Folklor 72 (2006), 95-106.

Barnouw, Viktor. An Introdiction to Anthropology-Ethnology U.S.A. 1975.

Benedict, Peter. Hukuk Reformu Açısından Başlık Parası ve Mehr. Ankara: Türkiye Kalkınma Vakfı Yayınları, 1974.

Biçurin, N. Ya. Sobranie Svedeniy o Narodah: Obitavşih v Sredney Azii v Drevnie Vremena. Moskva: İzdatelstvo AN SSSR, 1950.

Börübaşov, B. İ. "Regulirovanie İmuşestvennıh Otmoşeniy Kırgızov Po Adatu". Vestnik KRSU 9/1 (2009), 38-42.

Börübaşov, B. İ. İstoriya Gosudarstva i Prava Kirgızskoy Respubliki. Bişkek: y.y., 2015.

Buhûtî, Mansur b. Yunus. Keșşâfü'l-Kinâ 'ani'l-İknâ. 11 Cilt. Riyad: Vizaretü'l-Adâleti's-Suudiyye, 2000.

Butanaev, Viktor - Modorov, Nikolay. Kırgızskiy Kaganat: Pervıe Ego Praviteli i ih Deyatelnosti. (Altay: Word of The Great Altai, 2015/1), 4-8.

Cessas, Ahmed b. Ali er-Râzî Ebu Bekr. Ahkâmü'l-Kurân. 5 Cilt, Beyrut: Dârü İhyâi't-Türasi'l-Arabî, $1405 / 1985$.

Cumagulov, A. Semya i Brak u Kırgızov Çuyskoy Dalinı. Frunze: y.y., 1960.

Dobromılov, A. İ. Sud u Kirgiz: Turgayskoy Oblasti v 18-19 Vekah. Kazan: Tipo-Litografiya İmperatorskago Universiteta, 1904.

Dobrosmıslov, A.H. Taşkent v Proşlom i Nastoyaşşem: İstoriçeskiy Oçerk. Taşkent: y.y., 1912.

Düveys, Ahmed b. Abdurrazzak. Fetâva'l-lecneti'd-dâime li'l-buhusi'l-ilmiyye ve'l-iftâ. 19 Cilt. Riyad: Dârü'l-Âsime, 2003.

Ebü'l-Berakât Abdullah b. Ahmed b. Mahmud en-Nesefî. Tefsirü'n-Nesefí. 1 Cilt. Beyrut: Dârü'n-Nefâis, 2005. 
Ercoşkun, Tülay. Osmanlı Imparatorluğunda 19. Yüzyılda Evlilikve Nikaha Dair Düzenlemeler. Ankara: Ankara Üniversitesi, Sosyal Bilimler Enstitüsü, Doktora Tezi, 2010.

Erkul, Ali. "Eski Türklerde Evlenme Gelenekleri”, Türkler Ansiklopedisi. Ankara: Yeni Türkiye Yayınları, 2002.

Eşmuradova, N.D. "Pravove Polojenie Jenşin v Kırgızskom Traditsionnom Obşestve". Interactive Science 13 (2017), 184-185.

Fielstrup, F.A. İz Obryadovoy Jizni Kirgizov Naçala XX Veka. Yay. Haz. B.H.Karmışova-S.S.Gubaeva, Moskva: "NAUKA", 2002.

Gönen, Sinan. "Türk Kültüründe Kız Kaçırarak Evliliğ̈in Köy Seyirlik Oyunlarındaki İzleri”. Selçuk Üniversitesi Türkiyat Araştırmaları Dergisi 29 (2010), 45-55.

Grodekov, N. İ. Kırgızı i Karakırgızı Sırdarınskiy Oblasti: Yuridiçeskiy Bıt. Taşkent: Tipolitografiya S.I.Lathina, 1889.

Haraşî, Muhammed b. Abdillah. Şerhü Muhtasari Halil. 8 Cilt, Beyrut: Darü Sâdır, 1899.

İhsan Hınçer. "Türklerde Mehir ve Başlık", I. Uluslararası Türk Folklor Semineri Bildirileri. Ankara: T.C. Başbakanlık Kültür Müsteşarlığı Millî Folklor Araştırmaları Dairesi Yayınları. 9 Cild. 391-398.

İbn Âbidîn, Muhammed Emîn. Hâşsiyetu Reddu'l-Muhtâr ala'd-Durri'l-Muhtâr. 12 Cilt. Dâru İhyâi'tTurâsi'l-Arabî, Beyrut, ts.

İbn Kudâme, Abdullah b. Ahmed el-Makdisî. el-Mugnî fí fikhi'l-Imam Ahmed b. Hanbel eş-Şeybânî. Cilt, 6, 8, 10. Beyrut: Dârü'l-fikir, 1. Basım, 1984.

İbnü'l-Esir İzzuddin Ebi'l-Hasen Muhammed b. Muhammed b. Abdülkerim. el-Kamil fi't-Tarih. çev. A. Ağırakça-Abdulkerim Özaydın. İstanbul: Bahar Yayınları, 1985-1987.

İbnü'l-Hümam, Kemâlüddîn Muhammed b. Abdilvâhid b. Abdilhamîd es-Sivâsî. Şerhü Fethi'l-Kadir. 9 Cilt, Beyrut: y.y., 1970.

İnan, A. Makaleler ve İncelemeler. 1 Cilt. Ankara: Türk Tarih Kurumu, 1998.

Jusubaliev, Ali. Kırgızların İslamiyeti Kabulü. Ankara: Ankara Üniversitesi, Sosyal Bilimler Enstitüsü, Doktora Tezi, 2007.

Kaçın, Bülent. "Büyük Selçuklular'da Evlilik Merasimleri”. Selçuklu Medeniyet Araştırmaları Dergisi 2 (2017), 97-121.

Kadırov, K. Kırgızstan: Traditsii i Obiçai Kirgizov. Bişkek: Raritet, 2005.

Kambarova, G. E. "Salttuu Kudalaşuudagı Irım-Cırımdar: Tüştük Kırgızstan Misalında”. Nauka: Novıe Tehnologii i İnavatsii Kırgızstana 12 (2015), 206-207.

Kapusuzoğlu, Gökçen. "Çin Kaynaklarına Göre Türk Kültür Çerçevesinde Evlenme ve Cenaze Gelenekleri”. Tarih Araştırmaları Dergisi 34/58 (2014), 507-522.

Kariev, Aiitmamat. "Kırgız Biy Mahkemeleri Hakkında Kısa Bir Analiz”. Manas Sosyal Araştırmaları Dergisi 4 (2017) 89-101.

Kariev, Aiitmamat. "Kırgız Halkının Nişanlılık ile İlgili Örf-Âdetlerinin İslam Hukuku Açısından Analizi (18-19.yy.)". İnsan ve Toplum Bilimleri Araştırmaları Dergisi 9/5 (2020), 4167-4183.

Kevserî, Muhammed Zahid el-Hasan. Lamahâtü'n-Nazar fî Sîreti'l-İmam Zufer. Kahire: el-

Mektebetü'l-Ezheriyye li't-Türâs, 1948.

Kislyakov, N. A. Oçerki po İstorii Semi i Braka u Narodov Sredney Azii i Kazahstana. Leningrad: Nauka, 1969.

Koca, Salim. Türk Kültürünün Temelleri - II. Ankara: Kültür yayınları, 3. Basım,2010.

Koconaliev, S.K. Obıçnoe Pravo Kırgızov. Bişkek: Fond Soros Kırgızstan, 2000.

Köse, Nerin. "Eski Bir Evlenme Adeti ve Buna Bağlı Olarak Teșekkül Etmiş Halk Hikayeleri". Buca Eğitim Fakültesi Yayın Organı 2/3 (Ocak 1993), 81-87.

Makovetskaya, P.E. Materialı: Dlya İzuçeniya Yuridiçeskih Obıçaev Kirgizov. Omsk: Tipog. Okruj. Ştaba, 1886. 
764 | Kırgız Örf-Âdetindeki Kalın Uygulamasının İslam Hukuku Açısından Analizi (18-19. yy)

Malışev, N. M. Obıçnoe Semeynoe Pravo Kirgizov. Yaroslav: Tipografiya Guberskago Pravleniya, 1902. Maseviç, M.G. Materialı po İstorii Politiçeskogo Stroya Kazahstana. 3 Cilt, Alma-Ata: y.y., 1960.

Maydaer, Saadet. "Osmanlı Klasik Döneminde Kadınların Servet Edinme Yolları (Bursa Örneği)". Uludağ Üniversitesi Illahiyat Fakültesi Dergisi 15/2 (2006), 30-46.

Merdâvî, Alâuddin Ebü'l-Hasen Ali b. Suleyman b. Ahmed. el-İnsâffi ma'rifeti'r-racih mina'l-hilâf alâ mazhabi'l-Imam Ahmed b. Hanbel. Cilt 8. thk. Ebu Abdullah Muhammed Hasan İsmail. Beyrut: Darü'l-kutubi'l-ilmiyye, 1997.

Nalivkin, V. Oçerk Bıta Jenşinı Osedlogo-Tuzemnogo Naseleniya Ferganı. Kazan: y.y., 1886.

Omürbekova, Gulmira. "İstoriçeskoe Razvitie İnstituta Braçnogo Dogovora v Kırgızskoy Respublike”. Vestnik Ekonomiçeskoy Bezapasnosti 1 (2018), 216-218.

Ögel, Bahaaettin. Türk Kültürünün Gelişme Çağları. İstanbul: Millî Eğitim Basımevi, 1979, 2001.

Ögel, Bahaaettin. Dünden Bugüne Türk Kültürünün Gelişme Çağları. İstanbul: Türk Dünyası Araştırmaları Vakfi, 1. Basım, 1988.

Özer, Murat. “Ulupamir Kırgızlarında Evlilikle İlgili Gelenekler”. Uluslararası Türkçe Edebiyat Kültür Eğitim Dergisi 5/2 (2016), 870-889.

Polojenie ob Upravlenii Turkestanskim Kraem. Taşkent: y.y., 1903.

Polyakov, S. Everyday Islam: Religion and Tradition in Rural Central Asia. New York: y.y., 1992.

Potanov, L. P. Nauçnaya Mısl. Taşkent: y.y., 1930.

Proekt Uprazdneniya Narodnıh Sudov v Turkestanskom Krae. Taşkent: Tipografiya Kantselyarii General-Gubernatora, 1910.

Sâbûnî, Abdurrahman. Şerhu Kavâini'l-ahvâli'ş-şahsiyye es-Sûrî. 3. Cilt. Dımaşk: y.y., 1989.

Sağlam, H. "İslam Hukukunda Mehir Evlilik Sigortası mıdır?". Universal Journal of Theology 1/1 (2016), 1-19.

Saypidinov, B. R. "Braçno-Semeynı Otnoşeniya po Obıçnomu Provu Kırgızov v XIX v.". Vestnik KRSU 1/15 (2015), 49-53.

Serahsî, Ebû Bekr Şemsü'l-Eimme Muhammed b. Ebî Sehl Ahmed. el-Mebsût. 15 Cilt. Kahire: Matbaatü's-Saade, 1324-1331.

Seyyid Şerif el-Curcânî, Ali b. Muhammed b. Ali. Kitabü't-Tarifât. Thk. İbrahim el-Ebyârî. Kâhire: Dârü Îrân li't-Turâs, 1982.

Sost. Börübaşov, B. İ. Hrestometiya po İstorii Gosudarstva i Prava Kırgızstana: Ereje Tokmakskogo Crezvıçaynogo Sezda Biev 1893 Goda. 2 Cilt. Bişkek: y.y., 2008.

Starınkeviç, İ.D. Formu Zaklyuçeniya Braka u Turetskih Plemen Sibiri i u Koçevnikov Sredney Azii. 9 Cilt. S.Petersburg: MAE, 1930.

Stern, Jacobs. General Anthropology. (1968).

Şehzâde, Abdurrahman b. Muhammed b. Suleyman el-Küleybûlî. Mecmaü'l-enhur fí șerhi Multeka'lebhur. 4 Cilt. Beyrut: Dârü'l-kutubi'l-ilmiyye, 1998.

Şirbinî, Muhammed b. Ahmed el-Hatîb. Mugni'l-muhtâc. 6 Cilt. Beyrut: Darü'l-kütübi'l-i'Imiyye, 1993.

Tanrıverdi, Hasan. "İslam Hukukunda Boşanma Tazminatı (Mut'a)". Elektronik Sosyal Bilimler Dergisi 38/10 (Güz-2011), 443-463.

Taşağıl, Ahmet. Çin Kaynaklarına Göre Eski Türk Boyları. Ankara: Türk Tarih Kurumu, 2013.

Tegizbekova, Cıldız. Obıçnoe Pravo Kırgızov: Brak i Semya. Bişkek: Alatoo, 2016.

Türkdoğan, Orhan. "Evlenmedeki Başlık Geleneğinin Sosyolojik Açıklaması". Uluslararası Folklor Kongresi Bildirileri IV (1976).

Ünal, Ali. "Kırgız Toplumunda Evlilik Türleri". Hacetepe Üniversitesi Türkiyat Araştırmaları Üniversitesi Dergisi 25 (Güz 2016), 229-259.

Wufuer, Mairihaba. "On Uigur Wedding Traditions and Change". Sosyal ve Kültürel Araştırmalar Dergisi 5/ 9 (2019), 169-191. 
Yargl, Mehmet Ali. "Suudi Arabistan'daki Mehir Uygulamalarına Dair Bir İnceleme”. Kilitbahir 15 (Eylül 2019), 229-294.

Zagryajskiy, G. "Kara Kirgizi”. Gazeta Turkestanskoe Vedomosti (1871), 41.

Zagryajskiy, G. "Yuridiçeskiy Obiçay Kirgizov". Materialı Dlya Statistiki Turkestanskogo Kraya. 4. Basım, 1786. 